\title{
Notes
}

\section{Discriminatory Purpose and Mens Rea: The Tortured Argument of Invidious}

\section{Intent}

If one factor is uniform in a continuing series of events that are brought to pass through human intervention, the law would have to have the blindness of indifference rather than the blindness of impartiality not to attribute the uniform factor to man's purpose. The purpose may not be of evil intent or in conscious disregard of what is conceived to be a binding duty. Prohibited conduct may result from misconception of what duty requires.

$$
\text { -Justice Felix Frankfurter }
$$

In Washington v. Davis, ${ }^{2}$ the Supreme Court identified "the basic equal protection principle that the invidious quality of a law claimed to be racially discriminatory must ultimately be traced to a racially discriminatory purpose." Troubled by the disruptive consequences of wholesale in-

1. Cassell v. Texas, 339 U.S. 282, 293 (1950) (Frankfurter, J., concurring). Cassell involved an equal protection challenge to a Dallas County grand jury selection system that had resulted in the virtual exclusion of blacks from grand juries. Justice Frankfurter was responding to the state's argument that its jury commissioners had been acting in good faith when they chose only whites to serve.

2. 426 U.S. 229 (1976).

3. Id. at 240. The Supreme Court's route to this basic principle has been rather schizophrenic. Compare id. at 239-41 (prior cases demonstrate longstanding use of purpose requirement) and Gomillion v. Lightfoot, 364 U.S. 339, 347 (1960) (generally lawful acts unlawful when done to accomplish unlawful end) with Palmer v. Thompson, 403 U.S. 217, 224 (1971) (legislative motivation irrelevant in equal protection cases). See generally J. ELY, DemocRacy and Distrust: A Theory of Judicial Review 136-40 (1980) (discussion of Court's statements about discriminatory intent); Brest, The Supreme Court, 1975 Term-Foreword: In Defense of the Antidiscrimination Principle, 90 Harv. L. Rev. 1, 26-28 (1976) (same) [hereinafter cited as Brest, Antidiscrimination Principle]; Brest, Palmer v. Thompson: An Approach to the Problem of Unconstitutional Legislatize Motite, 1971 Sup. Cr. Rev. 95, 99-100 (same) [hereinafter cited as Brest, Legislative Motize].

This "basic principle" does not in general apply to statutory antidiscrimination actions, which instead employ an effects test. See, e.g., Washington v. Davis, 426 U.S. at 246-47 (contrasting equal protection intent requirement with disproportionate impact test of Title VII); Voting Rights Act Amendments of 1982, Pub. L. No. 97-205, sec. 3, 1982 U.S. Code Cong. \& AD. NEws (96 Stat.) 131,134 (to be codified at 42 U.S.C. $\S 1973 \mathrm{~b}$ ) (establishing effects test in Voting Rights Act vote dilution cases). 
validation of facially neutral laws, ${ }^{4}$ the Court defined discriminatory intent to include only actions taken with the conscious aim of disadvantaging protected minority groups. ${ }^{5}$ This Note examines the Court's restrictive definition of discriminatory intent by comparing it to the concept of mens rea in criminal law. The Note discusses how criminal and constitutional law both employ an "intent requirement" to serve the competing goals of moral condemnation and protection of legitimate activities. It then argues that differences between criminal and antidiscrimination law call for a less stringent intent standard in the latter.

The intent standard proposed by this Note expands the potential scope of equal protection litigation. The potential conflicts between antidiscrimination remedies and third-party interests would thus expand as well. In its final two sections, this Note discusses how courts may use the concept of the justificatory defense and their discretion in devising equitable remedies to ensure the proper protection of third-party interests.

\section{Intent Requirements in Criminal and Constitutional LaW}

The similar purposes of requiring proof of intent in criminal and constitutional law suggest that criminal law can provide valuable insight into the nature of wrongful intent in constitutional law. In both fields, requiring proof of intent to establish a violation allows courts to condemn offensive attitudes while protecting legitimate activities. Criminal and constitutional intent requirements are both sufficiently distinct from the law's other uses of intent ${ }^{6}$ and sufficiently similar to one another that criminal law provides a valuable analogue to constitutional law.?

4. Washington v. Davis, 426 U.S. at 248 \& n.14.

5. The Court has repeatedly confirmed the purpose requirement enunciated in Washington $v$. Dazis. See, e.g., Gity of Mobile v. Bolden, 446 U.S. 55, 69-74 (1980) (Stewart, J.); Personnel Adm'r v. Feeney, 442 U.S. 256, 274-79 (1979); Village of Arlington Heights v. Metropolitan Hous. Dev. Corp., 429 U.S. 252, 264-65 (1977).

6. In contract law, for example, the inquiry into state of mind revolves for the most part around so-called "objective factors": What were the reasonable expectations of the parties under the circumstances? See F. Kessler \& G. Gilmore, Contracts: Cases and Materials 95-97, 145-46 (2d ed. 1970). In statutory construction, the court seeks to give concrete meaning to a legislative enactment in light of the legislature's goals. See J. ELY, supra note 3, at 4 (legislature has less opportunity to overrule judicial judgments of constitutionality than it has to overrule undesirable statutory construction); Ely, Legislative and Administrative Motivation in Constitutional Law, 79 YALE L.J. 1205, 1213-14 (1970) (legislative intent in statutory interpretation cases more easily gleaned than in constitutional adjudication); Monaghan, Our Perfect Constitution, 56 N.Y.U. L. Rev. 353, 370 (1981) (courts' conduct more constrained in interpreting statutory or common law than in constitutional adjudication).

7. Alexander Bickel, the only scholar to mention the analogy between criminal and constitutional notions of intent, suggested in passing that criminal intent could be inferred from circumstantial evidence of what in fact happened, while the particular effect of concern to equal protection plaintiffs might be only a collateral result of a legislative desire to achieve some other end. See A. Bicker, THE. Least Dangerous Branch: The Supreme Court at the Bar of Politics 214-15 (1962), Bickel's reservation is less apt today, both because the Supreme Court has rejected the use of such an 


\section{A. Moral Condemnation}

Unlike a tort or breach of contract, a crime or constitutional violation. frustrates more than the expectations of the parties involved in a particular case. Both criminal and constitutional law speak to a wider audience. ${ }^{8}$ Most theorists have identified moral condemnation by the community as an essential element of traditional criminal offenses. ${ }^{9}$ This moral condemnation surfaces most clearly in so-called victimless crimes-or "morals offenses"-where prevention of involuntary injury to other parties plays a limited role. ${ }^{10}$ The criminal "not only harms the victim, he undermines rules and distinctions of significance beyond the specific case."11

A government's desire to injure minorities is "by [its] very nature odious to a free people whose institutions are founded upon the doctrine of equality."12 The state that shirks its obligation to provide equal protection of the law to all persons breaches faith with all those it governs. ${ }^{13}$ Paul Brest's condemnation of "racially selective sympathy and indifference"14 captures this moral judgment: An action violates the Fourteenth Amend-

inference in the criminal law, see infra pp. 114-15, and because the Court's current discriminatory intent standard does look at disparate impact.

8. Sep Fiss, The Supreme Court, 1978 Term-Foreword: The Forms of Justice, 93 Harv. L. REv. 1, 29 (1979) ("[C]ourts exist to give meaning to our public values, not to resolve disputes. Constitutional adjudication is the most vivid manifestation of this function . . . ."); Gewirtz, Remedies and Resislance, 92 YALE L.J. 585, 587 (1983) (essence of constitutional law lies in its idealizing); Hart, The Aims of the Criminal Lau', 23 LAw \& ConTEMP. ProBs. 401, 413 (1958) (criminal law defines "obligations of conduct which . . . community life impose[s] upon every participating member"); Wechsler, The Challenge of a Model Penal Code, 65 HARv. L. REv. 1097, 1098 (1952) (criminal law important for society as well as for individuals). Several commentators have pointed to the special role of the courts in expressing this societal moral judgment. See, e.g., A. Bickel, supra note 7, at 24-26 (judges uniquely situated to "support and maintain enduring general values"); Fiss, supra, at 11 (open texture of critical constitutional provisions requires courts to give them meaning).

9. See, e.g., Hart, supra note 8 , at 404 (criminal sanction distinguished from civil sanction by "judgment of community condemnation which accompanies and justifies its imposition"); Packer, Mens Ren and the Supreme Court, 1962 Sup. Cr. REv. 107, 148 ("moral blameworthiness should be indispensible" to community condemnation of criminal sanction).

10. See H.L.A. Hart, The Morality of the Criminal Law 39 (1962) (morals offenses reflect idea that primary justification of criminal punishment lies in expression of condemnation of immorality rather than in prevention of socially harmful acts); see also S. KADISH \& M. PAULSEN, Criminal Law and its Processes: Cases and Materials 54-55 (3d ed. 1975) (discussing literature concerning victimless crimes).

11. Calabresi \& Melamed, Properly Rules, Liability Rules, and Inalienability: One View of the Cathedral, 85 HARv. L. REv. 1089, 1126 (1972). Criminal sanctions reflect society's belief that simply paying the victim of a crime some amount of money after injuring him cannot, by itself, discharge the criminal's obligations, since the victim is not the only party whom the criminal wronged.

12. Hirabayashi v. United States, 320 U.S. 81, 100 (1943) (upholding curfew imposed on Japanese Americans during World War II).

13. Sep Cover, The Origins of Judicial Actizism in the Protection of Minorities, 91 YALE L.J. 1287, 1296-97 (1982) (baiting minorities not only injures victim group but also "deflect[s]" and "pervert[s]" other public purposes).

14. Brest, Antidiscrimination Principle, supra note 3, at 7-8 ("By the phenomenon of racially selective sympathy and indifference I mean the unconscious failure to extend to a minority the same recognition of humanity, and hence the same sympathy and care, given as a matter of course to one's own group.") (citation omitted). 
ment's command if it is more burdensome to some citizens only because they possess characteristics that the Constitution forbids the legislative process to consider. ${ }^{15}$

By imposing non-monetizable penalties such as stigma and imprisonment, criminal sanctions prevent the conversion of property rules into liability rules. ${ }^{16}$ Furthermore, the criminal cannot buy his way out after the fact by paying off a specific victim; crime is a social injury and whatever penalty a criminal pays is paid to society as a whole. Similarly, equal protection remedies do not allow the state to continue violating victims' rights by providing monetary compensation; ${ }^{17}$ indeed, because constitutional violations affect society as a whole, such compensation would be impossible. Instead, equitable remedies enjoin unconstitutional practices and order relief to restore victims to the positions they would have occupied absent any discrimination. ${ }^{18}$

Criminal and constitutional law recognize that certain rights are so essential to our society that they cannot be relinquished by those entitled to them or be acquired by other parties. ${ }^{19}$ The importance of these rights, reflected in the decision to regard them as inalienable, explains why attempting to deny them is so morally blameworthy.

\section{B. Protection of Legitimate Activity}

If condemnation of morally offensive attitudes were the sole concern of either criminal or constitutional inquiries into defendants' states of mind,

15. See J. ELy, supra note 3, at 157; Brest, Antidiscrimination Principle, supra note 3, at 5-8; Clark, Legislatiz' Motization and Fundamental Rights in Constitutional Law, 15 SAN DIEgo L. REv. 953, 964 (1978); Schnapper, Two Categories of Discriminalory Intent, 17 Harv. C.R.-C.L. L. REv. 31, 46-47 (1982).

16. See Calabresi \& Melamed, supra note 11, at 1126. In general, rights are protected by a combination of property and liability rules. Property rules require that someone who wishes to acquire a protected right negotiate a voluntary transfer with its owner. Id. at 1092 . Liability rules allow involuntary transfers but require that the acquiring party compensate the owner of the rights with an amount determined by the court. Id. at 1092, 1106-07.

17. But see Gewirtz, supra note 8, at 614 n.77 (discussing delayed remedies in structural antidiscrimination suits); $i d$. at 663-64 (discussing desegregation decrees which order "educational components" in lieu of eliminating all one-race schools).

18. See Milliken v. Bradley, 418 U.S. 717, 746 (1977); Davis v. Board of Schol Comm'rs, 402 U.S. 33, 37 (1971).

19. Calabresi \& Melamed, supra note 11, at 1111-15; $f f$ The Declaration of Independence para. 1 (U.S. 1776) ("Life, Liberty and the Pursuit of Happiness" are "unalienable Rights").

The decision to make rights inalienable reflects two determinations. First, it is self-paternalistic when, as with the Bill of Rights, society has decided that it will be better off in the long run if it denies itself the right to act in certain ways because the rights it denies to some today may be denied to others tomorrow. See Calabresi \& Melamed, supra note 11, at 1113. This notion dovetails with Ely's theory of the Fourteenth Amendment's expression of a right to virtual representation, see infra pp. 123-24. Second, the decision may reflect a desire to honor the preferences of those not directly involved: Even if, for example, some blacks would be satisfied with a tax reduction in exchange for attending inferior, segregated schools, we may feel as a community that such a transaction, voluntary though it may be, violates our fundamental political and ethical norms. See Calabresi \& Melamed, supra note 11, at 1112 . 


\section{Discriminatory Purpose}

courts might well establish a presumption that whenever a defendant was the cause in fact of a criminal or constitutional wrong, he had wrongful intent. In the past decade, however, the Supreme Court has rejected such a presumption in both criminal ${ }^{20}$ and equal protection cases. ${ }^{21}$

The imposition of harsh sanctions normally deters criminal behavior. ${ }^{28}$ In order to ensure that the law does not prevent wrongful conduct at the expense of interfering with legitimate behavior, the prosecution must demonstrate a nexus between the defendant's state of mind and the particular wrong that the law prohibits. ${ }^{23}$

In constitutional law, requiring plaintiffs to prove intent protects legislative autonomy. Democratic theory accords substantial weight to.a representative legislature's decisions about the aims a government ought to pursue and the means by which those aims ought to be reached. ${ }^{24}$ The equal protection clause allows courts to step in to overturn the legislature's balancing of various groups' interests only when that weighing has been tainted by constitutionally forbidden considerations. ${ }^{25}$

20. Sandstrom v. Montana, 442 U.S. 510, 517, 520-24 (1979) (jury instruction that law presumes that person intends ordinary consequences of voluntary acts violates due process requirement that state prove beyond a reasonable doubt every fact necessary to conviction).

21. Personnel Adm'r v. Feeney, 442 U.S. 256, 279 (1979) (proof of discriminatory intent requires showing that defendant "selected or reaffirmed a particular course of action at least in part "because of,' not merely 'in spite of,' its adverse effects upon an identifiable group").

22. See Packer, supra note 9 , at 126 ("'R]equiring a man to act at his peril is likely to inhibit his engaging in the activity in question. Where that activity is constitutionally protected, . . . the imposition of strict liability is an unreasonable restraint on his freedom to act.").

23. When the prosecution demonstrates that nexus, it shows that the defendant was acting purposefully with respect to the wrong prohibited by the applicable statute. If the state may properly prohibit that wrong, then purposeful action taken in order to cause that result is blameworthy. See infra note 62.

24. See A. BICKEL, supra note 7, at 19 ("policy-making power of representative institutions" is touchstone of American political system); Brest, Legislatize Motive, supra note 3, at 127-28 (legislature is proper body to decide "goodness" of policy); Fiss, supra note 8, at 6 ("general presumption in favor of majoritarianism").

25. The famous Carolene Products footnote four first suggested that the normal presumption of constitutionality may not operate in cases involving certain distinctions: "[P]rejudice against discrete and insular minorities may be a special condition, which tends seriously to curtail the operation of those political processes ordinarily to be relied upon to protect minorities, and which may call for a correspondingly more searching judicial inquiry." United States v. Carolene Prods. Co., 304 U.S. 144, 152 n.4 (1938). For recent judicial applications of this theory, see Graham v. Richardson, 403 U.S. 365, 371-72 (1971) (resident aliens constitute discrete and insular minority requiring heightened judicial protection); Sterling v. Harris, 478 F. Supp. 1046, 1051-52 (N.D. Ill. 1979) (applying Carolene Products analysis to the mentally ill), rev'd on other grounds sub nom. Schweiker v. Wilson, 450 U.S. 221 (1981).

Carolene Products both serves as the basis for modern procedural faimess theories of the Fourteenth Amendment and suggests their limits. Ely, for example, argues that the Constitution is designed to assure the right of political participation. To make that right meaningful, the polity must be restrained from acting on the basis of animus. Thus, when effective political participation is denied to minorities, courts ought to step in; courts should not assume, however, that every time minority interests lose out in the political process that such a result is unjustifiable. See J. ELY, supra note 3, at 73-179. For judicial expressions of this limit on judicial intervention, see Personnel Adm'r v. Feeney, 442 U.S. 256, 272 (1979) ("calculus of effects" is legislative, not judicial task); Village of Arlington Heights v. Metropolitan Hous. Dev. Corp., 429 U.S. 252, 265 (1977) (presumption that balancing function belongs to legislatures or administrators unless they act arbitrarily or irrationally). 
Moreover, demonstrating a nexus between the statutory or constitutional harm and the defendant's state of mind does not by itself override concerns for protecting legitimate activity or justify the moral condemnation that follows a judgment of criminality or unconstitutionality. Courts must also decide whether a defendant's deviation from the usual standard is justified by an end of greater importance than that served by obedience to criminal or constitutional law. ${ }^{28}$ Thus, consideration of intent operates to mediate the tension between condemnation and protection.

\section{The Effect on the Intent Standard of Differences Between Criminal and Constitutional Law}

The differences between criminal and constitutional law suggest that the intent requirement in equal protection cases should be less stringent than that employed in criminal prosecutions.

\section{A. The Role of the Victim}

Most criminal statutes ignore the victims' personal characteristics, except for the fact that they were injured by the activity that the statute forbids. ${ }^{27}$ Antidiscrimination law, however, manifests special concern for certain groups through the use of heightened scrutiny to analyze particular distinctions. ${ }^{28}$ This difference suggests that we should employ a less stringent intent requirement in equal protection cases. Furthermore, criminal law does not attempt to restore victims to the position they occupied

26. See infra pp. 128-29 (discussion of justification in criminal and constitutional law).

27. Cases like United States v. Feola, 420 U.S. 671 (1975) (prosecution under federal statute prohibiting attacks on federal officers), should perhaps be understood as specifying the status of the victim as a jurisdictional matter. There are also a few laws that specify the victim class in order to provide it with special prutection. See, e.g., Michael M. v. Superior Court, 450 U.S. 464 (1981) (California statutory rape law meant to protect underage girls from unwanted pregnancies); Dershowitz, The Special Victim is Not New in the Law, N.Y. Times, Mar. 27, 1977, §4, at 6, col. 3.

28. Normally, the state may justify a regulation that singles out and disadvantages a particular group by showing that the regulation is rationally related to the achievement of a legitinale state interest. Williamson v. Lee Optical Co., 348 U.S. 483, 487-89 (1955) (upholding restriction on opticians' prescribing power). Rational relation scrutiny, as the normal level of review is termed, almost never results in invalidation. Thus, judicial review affords little protection to most groups that lose out in the political process. If a regulation singles out and disadvantages a suspect class such as a racial minority, however, the state must show that its act is necessarily related to the achievement of a compelling governmental interest. McLaughlin v. Florida, 379 U.S. 184, 196 (1964). Strict scrutiny, as this form of review is termed, virtually always results in the invalidation of a challenged law. See Gunther, The Supreme Courl, 1971 Tern-Foreword: In Search of Evolving Doctrine on a Changing Court: A Model for a Newer Equal Protection, 86 HARv. L. REv. 1, 8 (1972). An "intermediate" level of scrutiny is applied to gender-based distinctions. See Craig v. Boren, 429 U.S. 190, 197 (1976) (measure upheld if substantially related to achievement of important governmental interest). Intermediate scrutiny reflects somewhat greater concern for the rights of women than is accorded to the interests of opticians, but decidedly less solicitude than is extended to racial minorities. See Personnel Adm'r v. Feeney, 442 U.S. 256 (1979). 
before the commission of the crime; rather, it leaves such attempts to civil tort actions ${ }^{29}$ or victim compensation statutes. ${ }^{30}$ The central concern of equal protection law is remediation for victims; ${ }^{31}$ any burden laid on equal protection defendants is incidental.

\section{B. The Burden of Proof}

The different burdens of proof faced by criminal prosecutors and equal protection plaintiffs also suggest that the intent requirement in constitutional cases should be less stringent than that employed in criminal trials. The Constitution requires that the government prove all necessary elements of a crime-including mens rea-beyond a reasonable doubt. ${ }^{32}$ In civil cases, including equal protection challenges, a plaintiff need usually prove the necessary elements of her case only by a preponderance of the evidence. $^{33}$ The higher standard required by the criminal law reflects society's desire not to deprive a defendant of his liberty or subject him to community opprobrium without extremely reliable proof of guilt; it also reflects a desire to protect the individual against the litigational advantages the state enjoys in prosecuting him. ${ }^{34}$ In addition, proving mens rea beyond a reasonable doubt does not lighten the prosecutor's burden in proving the other elements of the offense. ${ }^{35}$

Equal protection litigation does not impose this stringent burden of proof on plaintiffs. In fact, a mere showing of discriminatory intent effectively shifts the burden of persuasion to the defendant. ${ }^{36}$ Thus, it should

29. Sep Beach, Gelting Status and Getting Even, Time, Feb. 7, 1983, at 40 (discussing damage suits by crime victims); Press, Giving Victiins a Say in Court, Newsweer, Mar. 14, 1983, at 51 (discussing both damage suits and victim intervention in criminal proceedings).

30. See, e.g., N.Y. ExEc. LAw $\$ \S 620-35$ (McKinney 1982) (establishing Crime Victims Compensation Board to provide financial assistance to crime victims); Crime Victims Compensation Act, IlL. REv. STAT. ch. 70, $\S 71$ (1981) (giving victims right of action in state Court of Claims).

31. The purpose of the injunctive decree entered in an equal protection case is to "restore the victims of discriminatory conduct to the position they would have occupied in the absence of such conduct." Milliken v. Bradley, 418 U.S. 717, 746 (1974).

32. See Sandstrom v. Montana, 442 U.S. 510 (1979); see also Underwood, The Thumb on the Scales of Justice: Burdens of Persuasion in Criminal Cases, 86 YALE L.J. 1299, 1306-08 (1977) (discussion of purposes and scope of reasonable doubt requirement).

33. See Underwood, supra note 32, at 1300-01; of. Mount Healthy Gity School Dist. Bd. of Educ. v. Doyle, 429 U.S. 274, 287 (1977) (employing preponderance of the evidence test in First Amendment discriminatory intent case); Simon v. Honeywell, Inc., 642 F.2d 754, 755 (5th Cir. 1981) (use of preponderance of the evidence standard in Title VII antidiscrimination actions).

34. See Goldstein, The State and the Accused: Balance of Advanlage in Criminal Procedure, 69 YALE L.J. 1149, 1150 (1960) (state enjoys greater prestige and resources than most defendants); Underwood, supra note 32, at 1306-07 (same).

35. See In re Winship, 397 U.S. 358, 364 (1970) ("[T]he Due Process Clause protects the accused against conviction except upon proof beyond a reasonable doubt of exiery fact necessary to constitute the crime with which he is charged.") (emphasis added).

36. Once a plaintiff has proved discriminatory intent by a preponderance of the evidence, the state must rebut the presumption that the law is solely an expression of constitutionally impermissible motivation. See Village of Arlington Heights v. Metropolitan Hous. Dev. Corp., 429 U.S. 252, 270 n.21 (1977); Mount Healthy City School Dist. Bd. of Educ. v. Doyle, 429 U.S. 274, 285-87 (1977). 
be more difficult to establish the elements of a criminal offense than of a constitutional violation. Currently, however, equal protection law requires that plaintiffs always prove specific "purpose" to win, ${ }^{37}$ while criminal mens rea can be established in certain cases by showing purpose, knowledge, recklessness, or negligence. ${ }^{38}$

\section{The Interests of Third Parties}

In general, punishing a convict is unlikely to have significant harmful effects on third parties. ${ }^{39}$ The effect his punishment does have on third parties will consist in large part of desirable general deterrence: The fate of the defendant will dissuade others from acting as he did. ${ }^{40}$

In equal protection cases, by contrast, the defendant is usually a gov-

\footnotetext{
37. See infra pp. 122-23.

38. Sep infra p. 121.
}

There is another interesting difference between criminal and constitutional litigation: The Sixth and Fourteenth Amendments afford defendants in criminal cases the right to insist that a jury decide whether their states of mind are sufficiently culpable to justify community condemnation. See U.S. Const. amend. VI. ("In all criminal prosecutions, the aceused shall enjoy the right to a speedy and public trial, by an impartial jury . . ..'); Duncan v. Louisiana, 391 U.S. 145, 149, 156 (1968) (right to jury trial fundamental because of system's "insistence upon community participation in the determination of guilt or innocence," and therefore required in state criminal proceedings). In equal protection cases, by contrast, defendants do not possess the right to trial by jury because the Seventh Amendment's guarantee that "in Suits at common law, . . . the right of trial by jury shall be preserved," U.S. CoNST. amend. VII, does not apply to equity actions. United States v. Louisiana, 339 U.S. 699,706 (1950). Actions based on $\$ 1983$ thus do not fall within the amendment's ambit. McFerren v. County Bd. of Educ., 455 F.2d 199, 202-04 (6th Cir.), cert. denied sub nom. County Bd. of Educ. v. Walker, 407 U.S. 934 (1972); see also Comment, The Seventh Amendment and Cizil Rights Stalutes: History Adrift in a Maelstrom, 68 Nw. U.L. REv. 503 (1973) (applicability of amendment's guarantee to various antidiscrimination proceedings).

The reason for this difference is not hard to fathom and has little bearing on the nature of intent. In equal protection cases, the application of community standards would contradict the assumption that the plaintiffs were denied equal protection precisely because their interests or status were not those of the community from which a jury would be drawn. See Lawton v. Nightingale, $345 \mathrm{~F}$. Supp. 683, 684 (N.D. Ohio 1972) (in $\$ 1983$ action, right to jury trial makes no sense because someone "seeking to vindicate an unpopular right could never succeed before a jury drawn from a populace mainly opposed to his views").

This difference concerns only the trier of fact, and not the fact the trier is to ascertain. Moreover, this procedural difference suggests that the law has greater solicitude for the rights of criminal defendants, since juries possess mechanisms for leniency, such as nullification, that are unavailable to judges. Sep Taylor v. Louisiana, 419 U.S. 522, 529-30 (1975) (juries serve political function in guarding against prosecutorial abuse); United States v. Dougherty, 473 F.2d 1113, 1130-37 (D.C. Cir. 1972) (purposes underlying jury's ability to nullify).

39. This does not ignore the possibility that there may be heavy social costs-for example, prison construction expenses or public assistance for families of prisoners-attached to some forms of criminal punishment. One would presume, however, that the legislature considers these costs when enacting the statute. In any case, the judge is not expected to exercise equitable discretion in his treatment of an offender because of costs to third parties.

40. See S. KAdish \& M. PAUisen, supra note 10, at 26-40 (discussing theories of general and specific deterrence); Hart, supra note 8, at 408-09 (same). 


\section{Discriminatory Purpose}

ernmental entity, and a sizeable class of individuals has been injured. ${ }^{41} \mathrm{~A}$ plaintiff's victory will therefore affect the entire community. ${ }^{42}$ In a school desegregation case, for example, the integration decree often involves not only significant busing of pupils who were neither plaintiffs nor defendants, but also substantial expenditures on new facilities and educational programs. ${ }^{48}$ The burdens placed on innocent third parties therefore should cause courts to be more restrained in fashioning antidiscrimination remedies than they are in sentencing criminals. ${ }^{44}$

\section{The Problem of Group Intent}

Few areas of criminal law have occasioned more controversy than the treatment of group crimes and group intent. ${ }^{45}$ Criticism of prosecutions for group crimes generally focuses on the injustice of subjecting an individual to harsh criminal sanctions because of a group action for which he might not be responsible. ${ }^{4}$ Nonetheless, criminal law punishes group crime by prosecuting the individuals involved.

There is virtually no question that the harms which the law seeks to prevent fall within the purview of the government's prohibitory power. ${ }^{47}$

41. In school segregation cases, for example, the plaintiff class is often defined as all black children who are or will be students in the defendant school system. See, e.g., Armstrong v. Board of School Directors, 616 F.2d 305 (7th Cir. 1980); Brown v. Board of Educ, 84 F.R.D. 383, 394 (D. Kans. 1979). Prison reform litigation also often involves large classes with ever-changing memberships challenging institutional practices. See Powell v. Ward, 487 F. Supp. 917, 922 (S.D.N.Y. 1980) (class includes future as well as current prisoners), modified, 643 F.2d 924 (2d Cir.), cert. denied, 454 U.S. 837 (1981). For a discussion of the peculiar nature of structural litigation, see generally Chayes, The Role of the Judge in Public Law Litigation, 89 HARv. L. Rev. 1281 (1976); Fiss, supra note 8; Gewirtz, supra note 8.

42. "To undo the effects of the wrongs in the direct manner that the injunction contemplates, ... . the court must consider rearranging many pieces that were irrelevant to the question of violation." Gewirtz, supra note 8, at 604; see Brest, Antidiscrimination Principle, supra note 3, at 36 (controversial nature of antidiscrimination remedies stems from effects on third parties).

43. Gewirtz, supra note 8 , at 633 .

44. See infra pp. 131-34 (use of equitable discretion to take into account third party interests).

45. The issue has figured most prominently in the context of corporate crime and criminal conspiracy. See generally Detelopments in the Law-Corporate Crime: Regulating Corporate Behatior Through Criminal Sanctions, 92 HARv. L. REv. 1227 (1979) (examination of recent upsurge in efforts to regulate corporate activity through criminal proceedings) [hereinafter cited as Corporate Crime]; Note, The Conspiracy Dilennina: Prosecution of Group Crime or Protection of Individual Defendants, 62 Harv. L. REv. 276 (1948) [hercinafter cited as Note, Conspiracy Dilemma].

46. See Duke, Conspiracy, Complicity, Corporations, and Federal Code Reform, in Criminal. LAW AND the Corporate Counsel 147, 149 (A. Abramovsky ed. 1981) (difficulty lies in holding people responsible for what other actors did, not in holding them responsible for acts they themselves performed); Corporate Crime, supra note 45, at 1230 ("problematic" nature of corporate crime stems from prosecution of individuals within company); $c f$. Packer, supra note 9, at 116-18 (In discussing troublesomeness of United States v. Dotterweich, 320 U.S. 277 (1943) (president of drug company held criminally liable for shipping adulterated drugs), Packer notes that "if no one committed a crime, there was no crime for which Dotterweich could have been held vicariously liable.").

47. This is obviously true when a corporation performs an act which would be criminal if it were performed by an individual. See Note, Decisionmaking Models and the Control of Corporate Crime, 85 YALE L.J. 1091, 1093 (1976). Similarly, conspiracies to commit acts which the criminal law prohibits involve outcomes the state is empowered to prevent. 
Group crimes are often more dangerous than individual criminal activity because they involve "the strength, opportunities and resources of many [actors]," rather than those of only one. ${ }^{48}$ Furthermore, individuals are often more likely to act criminally when part of a group, since they substitute the group's moral scheme for society's moral strictures. ${ }^{49}$

The criticism leveled at prosecution of group crime is largely inapposite to antidiscrimination law, even though the intention of some group, whether a school board or a legislature, is at issue in almost every equal protection case. First, by its very terms, the equal protection clause contemplates "group offenses"; only the government, and not individuals, can violate it. ${ }^{\text {.0 }}$ Second, liability in an antidiscrimination case places no burden on the individual legislators who collectively violated the Fourteenth Amendment. ${ }^{\text {s1 }}$ Thus, the fairness question does not loom so large in constitutional law.

Just as in criminal law "the number and the compact give weight and cause danger," ${ }^{\text {"62 }}$ a defendant government's use of state power makes unconstitutional discrimination possible on a scale inaccessible to private parties acting alone. Furthermore, the state, by passing a law with the intention of violating the equal protection clause, is attempting to substitute its judgment for that contained in the Constitution.

There are, of course, obvious practical and philosophical difficulties in ascertaining legislative intent, ${ }^{\text {ss }}$ but the courts have long employed a fictitious construct in judicial review. ${ }^{54}$ Whatever the problems, the Supreme

48. Krulewitch v. United States, 336 U.S. 440, $448-49$ (1949) (Jackson, J., concurring); see, e.g., Callanan v. United States, 364 U.S. 587, 593-94 (1961); Marcus, Federal Conspiracy and Complicity Statutes-Panel Discussion, in CRIminal LAW and the CoRporate CounSEL, supra note 46, at 181, 181-82.

49. Sep Callanan v. United States, 364 U.S. at 594; Goldstein, On the Function of Criminal Law in Riol Control, in CRIME, LAW, AND SocietY 343, 352-56 (A. Goldstein \& J. Goldstein eds. 1971).

50. See Civil Rights Cases, 109 U.S. 3, 11-13 (1883) (Fourteenth Amendment meant only to reach state action).

51. U.S. Consr. art. I, $\S 6$, cl. 1, provides federal legislators with absolute immunity concerning the performance of their legislative duties. Eastland v. United States Servicemen's Fund, 421 U.S. 491, 501-03, 508 (1975); Doe v. McMillan, 412 U.S. 306, 311-13 (1973). Although this protection does not extend to state officials, United States v. DiCarlo, 565 F.2d 802, 805 (1st Cir. 1977), cert. denied, 435 U.S. 924 (1978), common law immunity has been conferred on state officials when they act in a legislative capacity. Tenney v. Brandhove, 341 U.S. 367, $372-79$ (1951) (state legislators are immune from suit under 8 U.S.C. $\$ 43$ [current version at 42 U.S.C. $\$ 1983$ (1976)]); see Bruce v. Riddle, 631 F.2d 272, 279 (4th Cir. 1980) (absolute immunity from $\S 1983$ suits for any official acting in "legislative" capacity). Any financial or organizational burden imposed by the courts will be passed along to the constituency. See supra pp. 118-19.

52. Marcus, supra note 48, at 182 (quoting nineteenth-century House of Lords discussion of Irish nationalist plot).

53. See Ely, supra note 6, at 1212-17 (discussing difficulty with discerning legislative motivation and problems with using motivation to invalidate otherwise valid laws); Note, Reading the Mind of the School Board: Segregative Intent and the De Facto/De Jure Distinction, 86 YALE L.J. 317, 322 n.9 (1976) (problems with discovering institutional intent).

54. See Dworkin, The Forum of Principle, 56 N.Y.U. L. REv. 469, 477 (1981) ("[T]here is no 
Court has repeatedly required courts to undertake such a determination in equal protection cases. ${ }^{55}$

\section{MFns Rea and the Constitutional Intent Standard}

Depending upon the offense, a judge or jury can find criminal culpability when defendants act with a variety of intentions. The similarities between criminal and constitutional law suggest that the Supreme Court should not restrict its definition of discriminatory intent to "purpose" alone.

\section{A. The Graded Spectrum of Intent in Criminal Law}

Several analytically distinct levels of intent can satisfy the mens rea requirement. ${ }^{58}$ The Model Penal Code ${ }^{57}$ recognizes four: purpose; ${ }^{58}$ knowledge ${ }^{50}$ recklessness; $^{60}$ and negligence. ${ }^{61}$ All involve attitudes which are morally offensive to the community. ${ }^{62}$

such thing as the intention of the Framers waiting to be discovered, even in principle. There is only some such thing waiting to be invented.").

55. See supra note 5 .

56. Sep Morissette v. United States, 342 U.S. 246, 252 (1952) (discussing "variety, disparity, and confusion" of traditional definitions of mens rea); see generally Robinson, A Brief History of Distinclions in Criminal Culpability, 31 Hastings L.J. 815 (1980) (development of spectrum of mens rea).

57. See Model Penal Code $\$ 2.02$ comment 2 (Tent. Draft No. 4, 1955) (purpose of Model Penal Code is to "rationalize" common law mens rea). The Supreme Court has recently employed the Model Penal Code's scheme in a variety of contexts. See, e.g., United States v. Bailey, 444 U.S. 394, 403-05 (1980) (prison escape); United States v. United States Gypsum Co., 438 U.S. 422, 444-45 (1978) (antitrust prosecution); United States v. Freed, 401 U.S. 601, 613 (1971) (Brennan, J., concurring) (Firearms Act violation).

58. A person acts purposely with respect to an element of an offense if "it is his conscious object to engage in conduct of that nature or to cause such a result ...." MODEI. PENAL Code $\S 2.02(2)(\mathrm{a})(\mathrm{i})$ (Proposed Official Draft 1962).

59. A person acts knowingly if "he is aware that it is practically certain that his conduct will cause [the forbidden] result." Id. $\S 2.02(2)(\mathrm{b})(\mathrm{ii})$.

60. A person acts recklessly when he "consciously disregards a substantial and unjustifiable risk" that his conduct will cause the result the law seeks to prevent. $I d . \S 2.02(2)$ (c). "The risk must be of such a nature and degree that, considering the nature and purpose of the actor's conduct and the circumstances known to him, its disregard involves a gross deviation from the standard of conduct that a law-abiding person would observe in the actor's situation," $i d$., although "even substantial risks may be created without recklessness when the actor seeks to serve a proper purpose," id. $\$ 2.02$ comment 3 (Tent. Draft No. 4, 1955).

61. A person acts negligently when he should have been aware of a "substantial and unjustifiable risk" that his actions would cause the result that the law forbids. Id. $\$ 2.02(2)(d)$ (Proposed Official Draft 1962). Negligence thus involves "constructive" foreseeability of the risk involved.

62. The intolerability of purposeful action is clear: If the criminal law "defines the minimum conditions of man's responsibility to his fellows," Hart, supra note 8 , at 410 , then a person who deliberately flouts these obligations surely deserves the community's condemnation.

There are some circumstances in which only a showing of purpose will suffice. See, e.g., United States v. Bailey, 444 U.S. 394, 405 (1980) (inchoate crimes); Haupt v. United States, 330 U.S. 631, 641 (1947) (treason). The law generally finds knowledge culpable, however, since by forbidding acts with a certain result, the law has already decided that no one should do them. See, e.g., Sandstrom v. Montana, 442 U.S. 510, 525-26 (1979) (homicide); United States v. United States Gypsum Co., 438 U.S. 422, 444-45 (1978) (criminal price-fixing). 


\section{B. The Purpose Requirement in Antidiscrimination Law}

The discriminatory intent standard developed by the Supreme Court in the wake of Washington $v$. Davis ${ }^{83}$ prohibits a finding of animus without proof of the most serious state of mind-purpose. ${ }^{84}$ Personnel Administrator of Massachusetts $v$. Feeney ${ }^{65}$ requires that a plaintiff prove that the challenged action was taken because it would injure a protected group." Village of Arlington Heights v. Metropolitan Housing Development Corporation ${ }^{67}$ demands proof that but for the conscious aim of disadvantaging minorities, the legislature would not have enacted the offending law..$^{68}$

In practice, no state of mind other than purpose can meet such an intent requirement, since knowledge, recklessness, and negligence all by definition describe mental states in which the government is pursuing an additional, legitimate goal. ${ }^{69}$ By articulating such a goal-and courts often

A reckless defendant did not actually know that his acts would cause the prohibited harm, but he was aware of the risk that such a result would ensue. The reckless person overweighs his own interests-the purpose of his acts-at the expense of abdicating his responsibilities to his fellows. See Wechsler, Symposiun on the Model Penal Code: Foreword, 63 Colum. L. REv. 589, 592 (1963); Wechsler, On Culpability and Crime: The Treatment of Mens Rea in the Model Penal Code, 339 ANNAls 24, 31 (1962).

Unlike the blameworthiness attending the other three states of mind, "the culpability of negligence is not the culpability of choice, but rather of failing to bring to bear one's faculties to perceive the risks that one is taking." Fletcher, The Theory of Criminal Negligence: A Comparative Analysis, $119 \mathrm{U}$. PA. L. REv. 401, 415 (1971). The decision to impose culpability for negligent behavior often reflects one of two perceptions: either the harm the law seeks to prevent is especially serious, as it is in homicide; or the defendant occupies a status which imposes upon him a duty of care which ignoranice should not excuse him from fulfilling. See Hart, supra note 8 , at 421 (discussing culpability of negligence); Packer, supra note 9, at 131 (same). A number of cases in which the Supreme Court has upheld criminal liability based on negligent behavior have involved corporate (that is, group) criminal activity. Id. See also supra pp. 119-20 (discussion of group crime).

63. 426 U.S. 229 (1976).

64. 426 U.S. at 240.

65. 442 U.S. 256 (1979).

66. "Discriminatory purpose' . . . implies that the decisionmakers . . . selected or reaffirmed a particular course of action at least in part 'because of,' not merely 'in spite of,' its adverse effects upon an identifiable group." Id. at 279. For applications of this standard, see, e.g., Harris v. McRac, 448 U.S. 297, 323 n.26 (1980) (upholding Hyde Amendment restriction on abortion against claim of foresecable discrimination against teenage women); Spangler v. Pasadena City Bd. of Educ., 611 F.2d 1239, 1245 (9th Cir. 1979) (Kennedy, J., concurring) (discussing right of school board to use neighborhood assignment plan with foreseeable segregatory consequences).

67. 429 U.S. 252 (1977).

68. Although proof that discriminatory intent was " $a$ motivating factor in the decision" removes the normal judicial presumption of deference to legislative balancing, id. at 265-66 (emphasis added), the defendant still can save its action by showing that "the same decision would have resulted even had the impermissible purpose not been considered." Id. at 270 n.21. For applications of this standard, see East Texas Motor Freight Co. v. Rodriguez, 431 U.S. 395, 403-04 \& n.7 (1977) (Title VII case); Winters v. Lavine, 574 F.2d 46, 64 (2d Cir. 1978) (deprivation of medicaid benefits to Christian Scientist).

69. The Model Penal Code's formulations of knowledge, recklessness, and negligence all expressly recognize that actors with these intents are pursuing some purpose other than causing the result that the law forbids. Model Penal Code $\$ 2.02$ comment 3 (Tent. Draft No. 4, 1955); spe supra notes 61-62.

The nonpurposiveness of many legislative acts which disproportionately burden minorities inheres in the legislative process. The legislature is almost always pursuing more than one end when it acts. 
make a strenuous effort to find one $\mathrm{e}^{20}$ - a defendant will be able to show that it acted in spite of, and not because of, the risk of injuring minorities.

\section{The Indefensibility of a Purpose Requirement in Equal Protection Cases}

The Supreme Court's condemnation of only purposeful discrimination is rooted in its incorrect balancing of the two goals of the intent requirement. Washington v. Davis ${ }^{71}$ expressed the Court's desire to avoid the "parade of horribles" that would accompany a disparate impact test. ${ }^{72}$ An intent requirement less strict than purpose, however, would better balance these concerns.

\section{Knowledge, Recklessness, and Negligence in Constitutional Law}

Because of the Constitution's and the courts' special concern for the protection of certain groups from defects in the political process, ${ }^{73}$ the middle ground occupied by knowledge, recklessness, and negligence ${ }^{74}$ need not consist of three analytically distinct states of mind in constitutional law. Unlike the relationship of a criminal to his victim, the legislature has a special responsibility to its constituency; under one formulation, the

See Village of Arlington Heights v. Metropolitan Hous. Dev. Corp., 429 U.S. 252, 265 (1977); A. BickEl, supra note 7, at 214. In addition, the purpose of the legislature is often simply to give effect to the voice of its constituents. See infra pp. 125-26 (recklessness and negligence of legislative acts can consist of giving effect to private discrimination).

70. See, e.g., Michael M. v. Superior Court, 450 U.S. 464, 494-96 \& nn.9-10 (1981) (Brennan, J., dissenting) (Court's decision justifying gender-based California statutory rape law as related to state aim of preventing teenage pregnancy was without evidence that prevention of pregnancy motivated passage of law); Railway Express Agency v. New York, 336 U.S. 106, 109 (1949) (upholding truck advertising ban as possibly related to safety considerations); see also J. EL.y, supra note 3, at 125 (court will invoke any possible permissible goal to save statute even if no agent of defendant has ever suggested it); Calabresi, Retroactivity: Paramount Powers and Contractual Changes, 71 Yale L.J. 1191, 1199 n.27 (1962) (noting "diligence" of courts' searches for acceptable rationale for challenged policies). Of course, "that a legislature seeks to advantage one group does not, as a matter of logic or of common sense, exclude the possibility that it also intends to disadvantage another." Personnel Adm'r v. Feeney, 442 U.S. 256, 282 (1979) (Marshall, J., dissenting). The current but for gloss placed on the intent requirement, however, makes it fairly certain that neither logic nor common sense will substantially affect the determination of intent.

71. 426 U.S. 229 (1976).

72. 426 U.S. at 248 \& n.14; see Brest, Antidiscrimination Principle, supra note 3, at 29 (because current effects of historical discrimination are so pervasive, effects test would result in wholesale invalidation of current laws); $c f . \mathrm{J}$. ELY, supra note 3, at 20 (when judges began to realize ramifications of expansive notion of due process clause, scope of clause was narrowed).

73. See supra p. 116.

74. See Packer, supra note 9, at 109-10 (criminal negligence as "half-way house" between traditional notions of intent and strict liability); $c f$. United States v. United States Gypsum Co., 438 U.S. 422 (1978) (criminal antitrust liability cannot be established by anticompetitive effects alone, but knowledge will satisfy intent requirement). The Model Penal Code views knowledge, negligence, and recklessness as occupying such a middle ground. Compare MODEL Penal Code \$§ 2.02(2)(b)-2.02(2)(d) (Proposed Official Draft 1962) (defining culpable states of mind) with id. § 2.05 (provision dealing with strict liability offenses). 
equal protection clause imposes a duty of "virtual representation" upon the legislature, an obligation that it consider the interests of all those whom its actions will affect. ${ }^{75}$ There is a potential conflict between the legislature's duty to be responsive to its constituency's desires (sometimes bigoted), and its duty of allegiance to the Constitution. The Fourteenth Amendment's special concern for minorities, ${ }^{76}$ however, requires that a legislature consider the rights of these groups when it makes its "calculus of effects." A legislature should be charged with either actual or constructive knowledge of potential burdens its acts will impose on minorities. ${ }^{77}$

\section{The Moral Culpability of All Intentional Discrimination}

The special constitutional concern for minorities that blurs the lines between knowledge, recklessness, and negligence also provides the basis for finding morally culpable intent when a plaintiff proves any of these states of mind.

The current intent standard, by focusing exclusively on the ultimate purpose of the state's action, insulates "means discrimination"78 from effective review. Because virtually any legislative decision can be described as furthering some "umbrella goal," such as promotion of the general welfare, ${ }^{78}$ most discriminatory conduct is not "purposeful," at least not in the sense that the legislature consciously wanted to burden minorities. Rather, it reflects the willingness of the state, in pursuit of a nondiscriminatory goal, to place disproportionate burdens on those groups who are least able to bear them and least able to complain effectively. ${ }^{\mathbf{8 0}}$

Given the cumulative and pervasive nature of past purposeful discrimination against blacks and women, courts should presume that legislatures

75. J. Ely, supra note 3, at 86 (Fourteenth Amendment "quite plainly imposes a judicially enforceable duty of virtual representation."); $c f . \mathrm{J}$. MASHsw \& R. MERRILL, INTRODUCTION TO THE American Public Law System: Cases and Materials 816 (1975) (discussing effect on standing doctrine in administrative law cases of government's obligation extending to all citizens).

76. See The Slaughterhouse Cases, 83 U.S. (16 Wall.) 36, 71 (1872) ("IT]he one pervading purpose ... lying at the foundation of [the Fourteenth Amendment was] . . the security and firm establishment of [the ex-slaves'] freedom, and the protection of the newly-made freeman and citizen from the oppressions of those who had formerly exercised unlimited dominion over him."); see Brest, Legislative Motive, supra note 3, at 108-09 (development of suspect classifications dependent on courts' sentiment that certain groups are often victimized by prejudice); Simon, Racially Prejudiced Governmental Actions: A Motivation Theory of the Constitutional Ban Against Racial Discriminalion, 15 SAN Diego L. REv. 1041, 1051, 1068-69 (1978) (function and significance of suspect classes derives from history of systematic discrimination against them).

77. Actual knowledge would correspond to either knowledge or recklessness, depending on how certain the legislature was that its act would adversely affect blacks or women, while constructive knowledge would parallel the culpable ignorance inherent in criminal negligence.

78. Schnapper, supra note 15 , at 32 ("means discrimination" refers to invidious consideration of race in selecting method used to achieve a previously selected objective).

79. See Ely, supra note 6, at 1246-47.

80. See supra p. 115-16 (rationale for special constitutional protection is certain groups' helplessness in political arena). 
know that some facially neutral laws or regulations will have "devastating" impacts upon minority opportunities. ${ }^{\mathbf{8 1}}$ Acting in the face of such knowledge $e^{82}$ "serve[s] only to perpetuate these [past] inequities in a different form. ${ }^{\text {"ss }}$ The state's willingness to let the burden continually fall on the same discrete and insular groups reflects morally offensive indifference. $^{\text {s4 }}$

Culpable, nonpurposeful state discrimination might also resemble recklessness or negligence. In a democracy, the purpose of state action is often to satisfy the majority's demands. ${ }^{85}$ Unfortunately, a majority may demand the exclusion of blacks or women. The current intent standard, which looks at the attitude of the state officials responsible for the challenged policy, rather than at the expressed motives of individual citizens, ${ }^{88}$ means the state can "effectively abdicate its responsibilities by either ignoring them or by merely failing to discharge them whatever the motive may be."87 The equal protection clause becomes little more than "a sterile promise [when] state involvement in possible private [discriminatory] activity [can] be shielded altogether from constitutional scrutiny [by claiming that the state's intent is simply to satisfy the citizenry.]"8s When the state indulges the discriminatory tastes of individual citizens, it "commit[s] the

81. See Personnel Adm'r v. Feeney, 442 U.S. 256, 260-61 (1979) (district court found, and Supreme Court accepted, that Massachusetts' preference law had foreseeable, devastating impact on women's employment prospects).

82. This seems to be the gloss put on "in spite of" by the Court. See Feeney, 442 U.S. at 278-79 (although claim that effects of veterans' preference were unintended was "disingenuous" and "[could not] seriously be argued," court refused to find discriminatory purpose); $c f$. Note, Absolute Veterans' Preference in Public Employment: Personnel Administrator of Massachusetts v. Feeney, 21 B.C.L. REv. 1110, 1140 (1980) (suggesting "in spite of" should not mean regardless of, but instead should reflect unbiased legislative balancing).

83. Gaston County v. United States, 395 U.S. 285, 297 (1969) (in Voting Rights Act case, court voided literacy test because defendant's longstanding intentional discrimination in education rendered blacks less able to pass test); see Griggs v. Duke Power Co., 401 U.S. 424, 430 (1971) (Title VII case noting role of inferior segregated schools in blacks' poor performance on employer's test); $c f$. Orr v. Orr, 440 U.S. 268, 279 n.9 (1979) (striking down Alabama alimony statute because it relied on past discrimination to justify current gender-based distinction). The present intent standard rejects such a "reliance" argument. See Feeney, 442 U.S. at 276-77 (Massachusetts' act does not "incorporate" intentional federal discrimination against women in the armed forces).

84. See supra pp. 113-14.

85. This presumption underlies the normal deference accorded to legislative determinations. See supra p. 115.

86. City of Memphis v. Greene, 451 U.S. 100, 114 \& n.23 (1981) (even when officials acted upon citizens' request, relevant intent was that of city council, not that of petitioning citizens).

87. Burton v. Wilmington Parking Auth., 365 U.S. 715, 725 (1961) (pre-Washington v. Davis decision striking down exclusion of blacks from restaurant in building owned by defendant, a state agency).

88. Norwood v. Harrison, 413 U.S. 455, 466-67 (1973) (striking down Mississippi textbook program providing books to segregated private schools). This sentiment seems to underlie "state action" cases, in which plaintiffs challenge legislative or administrative acts that give support or status to private discriminatory action which would not otherwise fall within the Fourteenth Amendment's prohibition. See generally G. Gunther, Cases and Materials on Constitutional Law 985-99, 1002-07, 1011-15, 1020-21, 1026-28 (10th ed. 1980) (discussion of state action cases). 
constitutional accounting error of treating the infringement of a constitutional right as a benefit rather than as a cost." ${ }^{\text {"80 }}$ This misperception of costs and benefits is precisely the necessary predicate of recklessness or negligence: Both states of mind describe actions that were unjustified in light of the risks they created.90

\section{A Broader Intent Standard is Superior to an Effects Test}

Many critics of the current purpose requirement propose replacing it with an effects test. An effects test examines the impact of a challenged act: If the act disproportionately injures a protected group, then the defendant's "good intent or absence of discriminatory intent does not redeem [it]." This Note's proposal to expand the definition of "discriminatory intent" to include knowledge, recklessness, and negligence would better serve the Constitution's twin goals of condemning socially offensive attitudes and protecting legitimate activity.

An effects test does not involve making the moral judgment about a state's good faith which an intent test requires. ${ }^{92}$ The failure of a state to treat its citizens equally violates a central constitutional principle, however; ${ }^{83}$ such dereliction ought to be condemned, and not simply invalidated as reflecting an unwise policy. Moreover, the choice of which groups to protect with an effects test must stem ultimately from our desire to remedy

89. Brest, Reflections on Motive Review, 15 SAN Diego L. Rev. 1141, 1144 (1978).

The Court's current atomistic perspective renders recklessness or negligence virtually impossible to prove. See City of Mobile v. Bolden, 446 U.S. 55, 74 (1980) (Stewart, J.):

[P]ast discrimination cannot, in the manner of original sin, condemn governmental action that

is not itself unlawful. The ultimate question remains whether a discriminatory intent has been

proved in a given case. More distant instances of official discrimination in other cases are of

limited help in resolving that question.

Since there is no way of determining what a hypothetical "reasonable legislature" might do, there is no predicate for finding recklessness or negligence.

90. City of Memphis v. Greene, 451 U.S. 100 (1981), is an example of a case where a recklessness standard would almost certainly have resulted in liability for the defendant. Acting on complaints by residents of an all-white enclave and despite opposing petitions by black citizens, id. at 143 n.9 (Marshall, J., dissenting), the City closed a street frequently used by blacks which passed through the white neighborhood. The Supreme Court, in upholding the City's decision in the face of Thirteenth and Fourteenth Amendment challenges (1) refused to examine the motives of the white citizens who had requested the closing, looking instead only at the City's purpose, id. at 114 \& n.23, which obviously was to satisfy the desires of the petitioning citizens; and (2) refused to give any weight to the fact that Memphis had segregated its public facilities as late as 1963, id. at 116 n.27.

Taken in isolation, as the Court chose to take it, the City's decision might simply have been a case where one group's interests trumped another group's competing interests. Taken in the context of Memphis' history of official segregation, however, the City's action reflected its persistent undervaluation of black interests.

91. Griggs v. Duke Power Co., 401 U.S. 424, 432 (1971) (explaining Title VII's effects test).

92. See Karst, The Costs of Motive-Centered Inquiry, 15 SAN Diego L. REv. 1163, 1164-65 (1978) (contrasting purpose requirement with effects test; former involves condemnatory aspect absent from latter); $c f$. Nagle, How the Right Learned to Love Earl Warren, WASH. MONTHLY, Oct. 1982, 50,53 (current constitutional doctrine involves disparagement of good faith of government officials).

93. See supra pp. 113-14. 
past purposeful and intolerable exclusion and to prevent such injuries from happening in the future. ${ }^{94}$ The standard which equal protection law employs should reflect these moral considerations.

Of course, equal protection law might adopt a modified effects test in which a defendant could vindicate its disproportionately burdensome acts by pointing to some alternative justification..$^{95}$ Such a modified effects test, however, would be little more than a requirement that acts with disparate effects be subjected to heightened scrutiny. Under such a test, a defendant would be able to justify its acts if it could show that they served some "compelling" or "important" state interest. It thus would contribute nothing more than an intent requirement; ${ }^{98}$ moreover, it would lack the Fourteenth Amendment's moral condemnation of discrimination, something which an intent requirement provides. Developing a broad conception of discriminatory intent as proposed in this Note better serves the goals of the equal protection clause.

An intent standard has another advantage over an effects test. Without conceding that there are nonculpable state motivations for differentiating among beneficiaries by race, there can be no principled justification for affirmative action. ${ }^{97} \mathrm{~A}$ strictly construed effects test would prohibit actions designed to aid those groups whose plight originally prompted modern antidiscrimination law. ${ }^{88}$ An intent standard, by recognizing that there

94. A strict effects test, in which proof of any disproportionate impact would invalidate a law, would destroy the legislature's balancing function, since such a test would require the state always to value the interests of protected groups more highly than the interests of other persons, no matter how insignificant the former or how substantial the latter.

If the Court's analysis in Washington v. Davis, 426 U.S. 229, $248 \mathrm{n.14}$ (1976), is correct, an effects test might be used to invalidate even such seemingly innocuous governmental actions as uniform sales taxes or bridge tolls, despite their obvious administrative advantages and the fairly insignificant burdens they normally place on minorities. Furthermore, continuing such practices would not be justified by the possibly tremendous costs that might be involved in developing alternatives that do not disproportionately disadvantage minorities.

95. The effects test employed in Title VII cases, for example, permits disproportionate impacts caused by job-related practices. See Dothard v. Rawlinson, 433 U.S. 321, 331-32 (1977) (proof of jobrelatedness would save regulations that disproportionately exclude women from prison guard positions); Griggs v. Duke Power Co., 401 U.S. 424, 431 (1971) (business necessity is "touchstone" in deciding whether to permit disproportionately burdensome practices); $c f .42$ U.S.C. $\$ 2000 \mathrm{e}-2(\mathrm{e})(1)$ (1976) (allowing discrimination based on gender, religion, or national origin when any of these is a bona fide occupational qualification-e.g., permitting hiring only men to be sperm donors).

96. The defendant's opportunity under such a modified effects test to put forward a "legislative necessity" explanation for disproportionately burdensome acts would parallel its opportunity under an intent standard to save its intentionally discriminatory acts by showing that they met the burden imposed by strict or intermediate scrutiny. See infra pp. 128-29 (discussion of heightened scrutiny triggered by showing of intent).

97. The justification for a principle that allows race-conscious affirmative action must rest on past, purposeful discrimination against blacks (or any other protected group). See Regents of Univ. of Cal. v. Bakke, 438 U.S. 265, 396 (1978) (Marshall, J.) (past pervasive discrimination makes bringing blacks into economic and professional mainstream "a state interest of the highest order").

98. See Fullilove v. Klutznick, 448 U.S. 448 (1980) (rejecting argument that equal protection clause prohibits minority set-aside program); supra note 76. 
can be compelling reasons for sometimes preferring race- or gender-based groups, ${ }^{99}$ and by granting the legislature authority to take actions to remedy these groups' disadvantaged positions, ${ }^{100}$ more nearly fulfills the aims of the antidiscrimination principle.

\section{WRONGFUl INTENT AND JUSTIFICATION}

In criminal law, proof of an actus reus and a mens rea usually suffices to establish criminal liability. ${ }^{101}$ The principal qualifications to this general rule are various defenses which enable a defendant to argue that, although he had the culpable mens rea, his act was nonetheless not blameworthy because of countervailing circumstances. ${ }^{102}$

In addition to this separate, justificatory stage, criminal law addresses the question of justifiability in its definitions of recklessness and negligence. Determining either involves a two-step process. First, actual or constructive awareness of a substantial risk must be proved. Second, the defendant's conscious purpose must be shown to be inadequate to justify acting despite the risk. ${ }^{103}$ Equal protection law also affords defendants the opportunity to justify their conduct.

\section{A. Discriminatory Intent and Heightened Scrutiny}

In current equal protection litigation, neither proof of a racial or gender-based classification nor proof of a discriminatory purpose and disparate effect leads automatically to a finding of unconstitutionality. Instead, proof of an explicitly discriminatory classification triggers the reviewing court's use of a more exacting form of scrutiny to determine whether the burden imposed is justified by some other legislative purpose. ${ }^{104}$ When a

99. See United Steelworkers v. Weber, 443 U.S. 193, 201-08 (1979) (upholding voluntary affirmative action plan in traditionally segregated craft union against Title VII claim); O'Neil, Preferential Admissions: Equalizing the Access of Minority Groups to Higher Education, 80 YALE L.J. 699, 718-41 (1971) (arguing for affirmative action in college admissions); $c f$. Ely, The Constitutionality of Reterse Racial Discrimination, 41 U. GHI. L. REv. 723, 730-31, 735 (1974) (prejudice against minorities triggers heightened scrutiny; such prejudice is absent from affirmative action cases, and distinctions are therefore not wrongful).

100. See Fullilove v. Klutznick, 448 U.S. 448, 472-84 (1980) (explicitly basing approval of minority set-aside program on Congress's broad power to remedy past discrimination); Regents of Univ. of Cal. v. Bakke, 438 U.S. 265, 387 (1978) (Marshall, J.) (when state acts to remedy effects of past discrimination, Constitution cannot stand as barrier).

101. See Model. Penal Code $\$ \S 2.01-2.02$ (Proposed Official Draft 1962) (requirement of voluntary act and culpable state of mind).

102. See N.Y. Penal Law \$ 35.05(2) (Consol. 1977) (justification defenses involve avoidance of result more serious than that which statute violated seeks to prevent); MODEL PENAl CoDE, supra note 58, art. 3 (same); see also S. KADISH \& M. PAULSEN, supra note 10, at 496-555 (materials on exculpatory and justificatory defenses); G. Willasas, Criminal Law: The General Part $\S$ 173-80 (1953) (discussion of necessity defense).

103. See Fletcher, supra note 62 , at 430 ; supra notes $60-61$.

104. See supra p. 116. 
plaintiff proves discriminatory intent and disparate effect, the defendant's opportunity to rebut the Arlington Heights presumption serves a similar justificatory function: If the defendant can show that it would have acted as it did even absent the desire to injure blacks or women-presumably because there were sufficient legitimate reasons for its action-the challenged measure will be upheld. ${ }^{105}$

Current equal protection doctrine assesses purpose without considering whether purposeful discrimination against the protected group is justified. ${ }^{108}$ Because showing both foreseeability and unjustifiability before employing heightened scrutiny would be redundant in ascertaining recklessness or negligence, ${ }^{107}$ actual or constructive foreseeability of a substantial risk of injury to minorities should by itself trigger the demand for justification. ${ }^{108}$

\section{B. Justification and Judicial Balancing}

At the intent-determining stage, this Note's approach would involve little judicial balancing, since courts are asked only to ascertain the foresee-

105. Village of Arlington Heights v. Metropolitan Hous. Dev. Corp., 429 U.S. 252, 270 n.21 (1977). It is unclear whether there is any effective difference between the scrutiny given explicit classifications and the scrutiny given facially neutral but intentionally discriminatory classifications. See Personnel Adm'r v. Feeney, 442 U.S. 256, 281 (1979) (Stevens, J., concurring). A similar question has arisen in Title VII cases. See Connecticut v. Teal, 102 S.Ct. 2525, 2535 (1982) (Title VII prohibits two distinctive violations: disparate treatment and disparate impact).

106. There is a disturbing circularity to the current method of assessing intent. Until the plaintiff proves either that a facially neutral measure in fact involves a race- or gender-based distinction or that a desire to disadvantage blacks or women motivated the adoption of a facially neutral law, see Personnel Adm'r v. Feeney, 442 U.S. 256, 274 (1979), courts will apply rational relationship scrutiny. As long as such low-level review is made, the fit between the articulated purpose and the challenged goal need not be particularly tight. The court, therefore, will not credit the plaintiffs' claims of legislative animus, as long as the defendant is able to articulate a plausible basis for its act. In Feeney, for example, as long as the Court was willing to assume a rational relationship, however tenuous, between an absolute lifetime veterans' preference and the goals of easing veterans' transitions into civilian life and encouraging service to one's country (and the Court's opinion pointed to no evidence to support either relationship), it would never find any discriminatory animus against women. Only when the court employs a more exacting fit standard, which it will do only once it has already determined the presence of discriminatory intent, will it find impermissible legislative intent.

107. If an act had foreseeable, unjustifiable consequences for minorities, then the state would not be able to argue at the scrutiny stage that those effects already found to have been unjustifiable in light of the state's purpose were justifiable in light of that same purpose.

108. In some kinds of equal protection cases, proving negligence may be impossible. As a theoretical matter, certain types of claims require showing a more seriously culpable state of mind. For example, in a jury selection case, the fact that a particular panel has no black members because an absolutely random selection process resulted in a monochromatic jury is indeed a sign that the system is working correctly. See Cassell v. Texas, 339 U.S 282, 291 (1950) (Frankfurter, J., concurring) (no equal protection violation if exclusion due to "uncontrolled caprices of chance"). If, however, a plaintiff proved that no blacks were on a particular panel because of purposeful discrimination by the state-leaving aside the thorny question of the prosecution's use of its peremptory challenges to intentionally strike minority jurors, see People v. McCray, 103 S.Ct. 2438, 2438-39 (1983) (Stevens, J., concurring in denial of certiorari); id. at 2439-43 (Marshall, J., dissenting from denial of certiorari); Swain v. Alabama, 380 U.S. 202, 221 (1965) -then the system used or the conviction obtained should be thrown out. 
ability of a substantial risk of injury to a protected group. At the liabilitydetermining stage, the courts' proper focus broadens somewhat to take account of concerns other than avoiding injury to victims.

The presence of some judicial balancing should not be troublesome for two reasons. First, only by allowing such balancing can constitutional law accommodate its competing goals of condemning morally offensive discrimination and protecting legitimate legislative activity. ${ }^{208}$ Second, the discretion of lower courts will, over time, come to be controlled by the accretion of precedent. ${ }^{110}$ Certain state aims will come to be viewed as sufficiently important to justify some foreseeable impact, while others will not. ${ }^{111}$

\section{The Effects on the Justificatory Stage of Broadening the Intent Standard}

One result of increasing the number of cases in which heightened scrutiny is employed may be to dilute slightly the strictness of such scrutiny. ${ }^{112}$ Such a result should not dissuade courts from applying slightly less heightened scrutiny to intentionally discriminatory state action if this Note's conception of discriminatory intent is adopted.

First, the stringency of the current standard is due in large part to its development as a response to explicit racial distinctions designed to disadvantage blacks. ${ }^{118}$ By hypothesis, however, knowing, reckless, and negli-

109. Without some balancing, even a de minimis foresecable effect could not justify pursuit of even the most compelling state goal. See supra note 94.

The alternative would be to allow every legislative determination to survive judicial scrutiny regardless of how purposeful its injury of protected minorities. Such a course would essentially write the Fourteenth Amendment out of the Constitution. Nor would enacting a per se rule against racial classifications solve this problem. First, the state would still be able to engage in "means discrimination," by picking an umbrella goal and carefully writing its legislation so that the class burdened or excluded was roughly identical to blacks or women. See Gomillion v. Lightfoot, 364 U.S. 339, 341 (1960) (complicated redrawing of town boundary disenfranchised all but four or five of 400 black voters). Second, such a rule would also make affirmative action impossible. See supra pp. 127-28.

110. This accretion of precedent and the constraints imposed by a hierarchical judicial system are essential to control of judicial discretion. See E. LEVI, AN INTRODuction To Legal Reasoning 6-7 (1949); K. Llewel.lyn, The Bramble Bush 56-69 (2d ed. 1951).

111. The Court has developed such a clarification of permissible and impermissible goals to analyze explicit gender-based discrimination. See, e.g., Michael M. v. Superior Court, 450 U.S. 464, 470-73 (1981) (prevention of teenage pregnancy justifies gender-based statutory rape law); Frontiero v. Richardson, 411 U.S. 677, 688-91 (1977) (Brennan, J., plurality opinion) (additional ease in administering program does not justify gender-based proof of dependency requirements).

112. In other words, there may be cases in which a substantial disproportionate impact was (or should have been) foreseeable, and the defendant was thus acting intentionally, but the act was nevertheless justified because of the purpose that motivated it. Strict scrutiny will therefore no longer be "strict in theory but [always] fatal in fact." Gunther, supra note 28, at 8; see Note, A Madisonian Interpretation of the Equal Protection Doctrine, 91 YALE L.J. 1403, 1416-17 (1982) (value of "rhetoric of absolutes" in constitutional law).

113. See Schnapper, supra note 15, at 45 (inadequacy of Court's holding in Feeney due to fact that tools used to assess intent were developed in era when Court reviewed obvious discrimination). 
gent acts do not have such disadvantaging as their purpose. A state interest that is not compelling enough to justify a disparate impact on minorities and the stigmatic harm of state-enforced racial distinctions, ${ }^{114}$ might be important enough to justify a disparate impact absent such stigmatic injury. ${ }^{115}$

Second, the strictness of current strict scrutiny seems in large part responsible for the Supreme Court's artificial restriction of the concept of discriminatory intent. ${ }^{116}$ The middle course this Note proposes trades some of the rhetorical value of current heightened scrutiny for nonperfunctory judicial review of significantly more state action having the effect of perpetuating blacks' disadvantaged status.

\section{Remedial Implications of a Broader Definition of DISCRIMINATORY INTENT}

The most significant differences between criminal and constitutional law lie in how they treat violators after liability is established and how that treatment affects third parties. ${ }^{117}$ The remedial stage of an equal protection case provides the proper opportunity to consider the interests of third parties.

\section{A. Considering Third-Party Interests at the Remedial Stage}

The flexibility of equitable remedies ${ }^{118}$ affords the most appropriate opportunity for considering the claims of third parties. The intent- and

114. See Brown v. Board of Educ., 347 U.S. 483, 494 (1954) (state segregation of black school children "generates a feeling of inferiority as to their status in the community that may affect their hearts and minds in a way unlikely ever to be undone"); Brest, Legislatize Motive, supra note 3, at 116 \& n.109 (very act of adopting racial distinctions is insult to minorities).

Under the scheme proposed by this Note, as in current doctrine, an invidious racial classification would virtually never pass muster. Rather, the result is likely to be that some foreseeably burdensome acts will be upheld. Their number will certainly be fewer than is currently the case, however, since the present intent standard permits all neutral acts to survive in spite of their adverse consequences.

115. For example, in Washington v. Davis, 426 U.S. 229 (1976), the Court might well have upheld the challenged examination on the theory that, although it had a foreseeable disparate impact, it was the best test of the qualities required to achieve the indisputably important state interest in a competent police force. In reaching such a decision, the reviewing court should take into account the defendant's efforts to ameliorate the disparate impact by extensive minority recruiting or coaching, as the Washington r. Daxis court implicitly did, id. at 235.

At the same time, a court should conclude that explicitly banning blacks from the department because blacks were on average less qualified than whites would not be justified by even a fairly significant increase in police efficiency, either because such a decision would impermissibly stigmatize blacks or because the predictive value of race rests in large part on past impermissible state discrimination. See Underwood, Law and the Crystal Ball: Predicting Behatior with Statistical Inference and Individualized Judgmenl, 88 YALE L.J. 1408, 1434-36 (1979) (explaining hostility to use of race as predictive factor).

116. The Supreme Court, faced with what it wrongly perceived as a choice between finding all foreseeably discriminatory acts intentional and thus overturning the laws wholesale, or adhering to a purpose standard and netier overturning such acts, chose the latter course. See supra p. 123.

117. See supra pp. 118-19.

118. Brown v. Board of Educ., 349 U.S. 294, 300 (1955) ("Traditionally, equity has been charac- 
liability-determining stages of an equal protection case concern solely the defendant's attitudes toward the plaintiff class, although the defendant's attitude towards third parties may provide some basis for comparison. ${ }^{119}$

At the remedial stage a court can explicitly consider other social interests. ${ }^{120}$ Explicitly making such determinations would make the development of standards through appellate review far easier than is currently possible: Because findings of intent are findings of fact, ${ }^{121}$ the present system does its balancing at the intent-determining stage and severely constrains appellate review.

In addition, although explicit balancing at the remedial stage makes manifest the existence of a right-remedy gap, ${ }^{122}$ acknowledging that gap can provide an impetus for non-judicial actors to pursue greater remediation for victims than courts provide. ${ }^{123}$ Moreover, the dignitary interests of victims of intentionally discriminatory conduct are better served by condemnation of governmental carelessness than they are by the current definition of discriminatory animus, which always allows judicial actors to claim that they fully cure all equal protection violations. ${ }^{124}$

\section{B. A Spectrum of Discriminatory Intent and the Remedial Enterprise}

The touchstone of equitable relief is that "the nature of the violation determines the scope of the remedy." ${ }^{.125}$ The nature of an equal protection

terized by a practical flexibility in its shaping its remedies and by a facility for adjusting and reconciling public and private needs.") (citation omitted).

119. Regardless of the other concerns a defendant is seeking to serve, its foreseeably discriminatory act reflects an intent to place a burden on the plaintiffs which it might have placed on a different group or on no one at all.

120. See Milliken v. Bradley, 433 U.S. 267, 280-81 (1977) (in formulating equitable decrees, courts should look at interests other than plaintiff's'); Swann v. Charlotte-Mecklenburg Bd. of Educ., 402 U.S. 1, 16 (1971) (equitable decree requires "balancing . . . of individual and collective interests"); Note, Institutional Reform Litigation: Representation in the Remedial Process, 91 YALE L.J. $1474,1484-88$ (1982) (proposing joinder of third parties at remedial stage).

121. Pullman-Standard, Inc. v. Swint, 456 U.S. 273, 285-90 \& n.16 (1982) (discriminatory intent is "pure" finding of fact governed by "clearly erroneous" standard of Fed. R. Civ. P. 52(a)).

122. A right-remedy gap occurs when a court is either unable or unwilling to provide the victims of a constitutional violation with a remedy that will vindicate their rights. See Gewirtz, supra note 8, at $655-74$.

123. See S. ReP. No. 417, 97th Cong., 2d Sess. 15-39 (1982), reprinted in 1982 U.S. Code CoNG. \& AD. NEwS, 177, 192-217 (effectively overruling Court's imposition of intent requirement in Voting Rights Act cases); Gewirtz, supra note 8, at 672-73 (maintenance of principle in face of rightremedy gap lends moral authority to those who seek to vindicate it more fully). As Alexander Bickel noted, "The effectiveness of principle is not less because we are allowed to admit that we do not live up to it when we don't." A. Bickel, supra note 7, at 96.

124. See Fiss, supra note 8, at 54-55 (courts' desire not to appear impotent leads them to tailor rights so they can claim to be providing full relief).

125. Swann v. Charlotte-Mecklenburg Bd. of Educ., 402 U.S. 1, 16 (1971). Bul see Fiss, supra note 8 , at $47-48$ (object of remedy should be to eliminate threat to constitutional values; violation simply triggers courts' remedial powers). 
violation depends upon its disproportionate impact and the dignitary insult inherent in the state's having acted to cause such an impact. ${ }^{126}$

Under current equal protection doctrine, the scope of a violation varies solely in terms of its effects, since the intent involved-purpose-remains constant across all violations. ${ }^{127}$ If less culpable states of mind were to meet the intent requirement, as this Note proposes, then the scope of the violation would also vary with the degree of discriminatory intent proved. ${ }^{128}$ As the Court recognized last Term in Guardians Association v. Civil Service Commission, ${ }^{128}$ "[i]t is not uncommon in the law for the extent of a defendant's liability to turn on the extent of his knowledge or his culpability,"1so and therefore for the remedy a victim of discrimination receives to depend on the violator's state of mind. If the determination of a remedial decree depends on balancing two quantities-the victims' interests and the legitimate concerns of third parties-the decree will thus be affected by the magnitude of the violation of the victims' rights: As the scope of a violation narrows, the relative weight of third party interests will increase. ${ }^{\text {131 }}$

126. See Strauder v. West Virginia, 100 U.S. 303, 308 (1879) (state's exclusion of blacks from juries "practically a brand [of inferiority] upon them"); Brest, Antidiscrimination Principle, supra note 3, at 8-11 (stigmatic harm of intentional discrimination); supra note 114 . This understanding of the scope of the violation underlies the intuition that de jure segregation is more harmful than de facto segregation; the insult of the state's having isolated blacks adds to the effects of that isolation.

127. Without some effect, no one would have standing to challenge a legislature's allegedly discriminatory measure. Such standing, however, need not rest on more than a de minimis actual effect, because the insult inherent in discriminatory conduct exacerbates that disparate impact. Spe Ely, supra note 6 , at 1252 n.139.

128. A purposeful violation would be more serious than a negligent violation even if both had the same effect. An analogy from criminal law might prove helpful here. All homicides have the same material effect-a dead body. Nevertheless, we believe purposeful homicide to be more blameworthy than reckless homicide, and we punish murder more severely than we punish manslaughter.

129. 103 S.Ct. 3221 (1983).

130. Id. at 3230 n.20 (White, J.). Guardians held that a private plaintiff in a Title VI suit could obtain prospective relief simply by showing discriminatory effect, but was barred from obtaining retrospective relief unless discriminatory intent were proved as well.

131. Some interests that cannot trump curing purposefully discriminatory violations might outweigh providing full or partial relief to victims of negligently discriminatory conduct. See supra note 115; $f$. City of Mobile v. Bolden, 446 U.S. 55, 80-83 (1980) (Blackmun, J., concurring) (agreeing with dissenters that purposeful discrimination had been shown, but concurring in rejection of district court remedial decree because remedy was too sweeping).

There are a vast array of potential remedial tools from which courts can choose, depending on the type of violation shown. For example, they can make their decrees prospective or retroactive, order backpay, establish numerical guidelines, and order a variety of forms of direct compensation for members of a class who can prove actual injury. In addition, a court faced with a purposefully discriminatory defendant might order a more specific remedial decree than it would otherwise formulate in order to minimize the defendant's chances for successful evasion of its remedial obligations. See, e.g., City of Port Arthur v. United States, 103 S.Ct. 530 (1982) (prophylactic voting rule to prevent future deprivation); Milliken v. Bradley, 433 U.S. 267, 283-86 (1977) (approving special remedial programs for victims of school segregation); Singleton v. Jackson Mun. Separate School Dist., 419 F.2d 1211, 1218 (5th Cir. 1969) (en banc) (specifying number of black teachers to be assigned to each school), ret'd on other grounds, 396 U.S. 290 (1970); Morgan v. Kerrigan, 388 F. Supp. 581, 583 (D. Mass. 1975) (ordering hiring of black teachers until percentage in school system approximated representation in 
Here too, then, this Note's suggestion will result in an overt rightremedy gap: Not all the effects of discriminatory acts will be cured, despite the compensatory thrust of antidiscrimination law. This gap, however, is the result of an expansion of the right, through a more comprehensive understanding of discriminatory intent. ${ }^{132}$ Ultimately, candor about remedial imperfection reflects greater judicial integrity than does the current disingenuous definition of discriminatory intent. ${ }^{\text {ss }}$

-Pamela S. Karlan

population), aff d, 530 F.2d 431 (1st Cir.), cert. denied, 426 U.S. 935 (1976).

132. In general, right-remedy gaps are caused by courts' contracting the available remedies for a violation. See Freeman, Legitimating Racial Discrimination Through Antidiscrimination Law: A Critical Review of Supreme Court Doctrine, 62 MinN. L. REv. 1049, 1102-19 (1978); Gewirtz, supra note 8 , at $655-74$.

133. Although Calabresi argues that subterfuges are sometimes necessary to conceal from a society its inability to adhere to its principles, see G. Calabresi \& P. BobBrtt, Tragic Choices 17-28 (1978), Gewirtz persuasively argues for judicial candor in the face of a right-remedy gap. In addition to such honesty providing other actors with moral authority and the impetus to seek a fuller realization of the right than the courts are able or willing to provide, see supra note 123, candor protects the right against insidious encroachment:

[S]ubterfuge carries a serious risk that the boundaries of any compromise of victim rights will

be blurred. Candor helps to prevent slippage-that is, judicial action that ends up allowing a gap between right and remedy beyond what is justified and beyond what was initially thought reasonable. By requiring everyone to face up to the remedial compromise, candor facilitates the limitation and control of compromise.

Gewirtz, supra note 8, at 670 . The Supreme Court, by hiding its compromises of blacks' and women's rights to have their interests fairly weighed, has allowed a far wider gulf to develop between rights and remedies than a more honest definition of intent would have engendered. 